\title{
Memories of Music in Political Detention in Chile under Pinochet
}

DOI:

10.1080/13569325.2018.1450742

\section{Document Version}

Accepted author manuscript

Link to publication record in Manchester Research Explorer

\section{Citation for published version (APA):}

Chornik, K. (2018). Memories of Music in Political Detention in Chile under Pinochet. Journal of Latin American Cultural Studies, 27(2), 157-173. https://doi.org/10.1080/13569325.2018.1450742

\section{Published in:}

Journal of Latin American Cultural Studies

\section{Citing this paper}

Please note that where the full-text provided on Manchester Research Explorer is the Author Accepted Manuscript or Proof version this may differ from the final Published version. If citing, it is advised that you check and use the publisher's definitive version.

\section{General rights}

Copyright and moral rights for the publications made accessible in the Research Explorer are retained by the authors and/or other copyright owners and it is a condition of accessing publications that users recognise and abide by the legal requirements associated with these rights.

\section{Takedown policy}

If you believe that this document breaches copyright please refer to the University of Manchester's Takedown Procedures [http://man.ac.uk/04Y6Bo] or contact uml.scholarlycommunications@manchester.ac.uk providing relevant details, so we can investigate your claim.

\section{OPEN ACCESS}


* This is an Accepted Manuscript of an article published by Taylor \& Francis in the Journal of Latin American Cultural Studies, 27.2 (2018), 157-173. Available online at:

https://www.tandfonline.com/doi/full/10.1080/13569325.2018.1450742.

\title{
Memories of Music in Political Detention in Chile under Pinochet
}

\section{Katia Chornik}

\begin{abstract}
Music was commonly present in political detention centres during General Augusto Pinochet's dictatorship (1973-1990), and has had important roles in post-dictatorship commemorations. However, music has received limited attention in cultural studies discussions of the Pinochet regime. This article examines a selection of memories of musical experiences of three former political prisoners, elicited through personal interviews. After contextualising the topic and discussing methodology, I present and discuss recollections of experiences in direct relation to torture and other cruel, inhuman and degrading treatment. By looking closely at the relationships between the musical experiences, genres and pieces remembered by the interviewees, a number of commonalities have emerged. However, I argue that these testimonies should be viewed in their uniqueness and specificity, and that the findings of this article are not necessarily representative of the experiences lived by the tens of thousands who went through political detention under Pinochet. This article also considers some of the ethical issues around work on human rights violations, and calls for recognition of the importance of archival and documentary work in relation to social and communal memory.
\end{abstract}

Keywords: music, testimony, cultural memory, human rights, Chile, Pinochet, dictatorship.

'Music can move people, and music can lead us to the greatest point of sisterhood and brotherhood. Love is very often expressed through music. But what can be used for love can also be used for violence.'

Ariel Dorfman (Tofft 2010, 0:40-0:57)

\section{Introduction}

Pinochet came to power through a military coup on 11 September 1973, overthrowing President Salvador Allende, who had been elected in 1970 with the support of the Unidad Popular coalition. ${ }^{1}$ Among the measures taken by Pinochet's dictatorship to consolidate its power and suppress dissent was the setting up of 1,168 centres for political detention, which were run by the secret services Dirección de Inteligencia Nacional (DINA) and Central Nacional de Informaciones (CNI), the armed forces and the police. Torture was a central pillar in these centres. According to the report of the truth commission Comisión Nacional sobre Prisión

\footnotetext{
${ }^{1}$ Unidad Popular was formed in 1969 by the following parties: Partido Radical, Partido Socialista, Partido Comunista, Movimiento de Acción Popular Unitario, Partido de Izquierda Radical and Acción Popular Independiente. In 1973, Izquierda Cristiana and MAPU Obrero y Campesino joined the coalition.
} 
Política y Tortura, aka Comisión Valech (2004, 255-297), common methods included beatings, injuries, hangings, forced positions, application of electricity, confinement in subhuman conditions, deprivation of nourishment and sleep, asphyxia, exposure to extreme temperatures, mock executions, witnessing torture and executions of others, stripping, sexual assault, threats, humiliation and abuse. The report also briefly mentions music in relation to eight detention centres $(317,390,415,444,445,453,517,529)$. All of these references briefly state that music was employed as a background to torture, but no further information or analysis is provided. $^{2}$

I began researching the topic of music and political detention in the early 2000s. My work has demonstrated that music was present in a larger number of detention centres than those identified by the Valech report: so far I have found evidence relating to thirty centres, from clandestine torture chambers to concentration camps and prisons. Many inmates had musical experiences of some form, whether passive or active, while in detention. This phenomenon has occurred in regimes across time and place, for instance in Nazi and Gulag camps, or in South Africa during Apartheid, to name a few. As John Blacking $(1973,107)$ asserted, 'remarkable cultural developments can take place in societies in which man's humanity is progressively abused, restricted, and disregarded.' Music has also had an important role in post-dictatorship cultural commemorations dealing with the legacy of Pinochet's Chile, such as the choir of former prisoners Voces de la Rebeldía, formed in 2013 (Chornik 2013). Despite its relevance in these contexts, music has had a limited place in Latin American cultural studies scholarship dealing with topics relating to the Pinochet regime. ${ }^{3}$ This is not surprising, given the narrow presence of music in cultural studies in general.

Rather than drawing on excerpts from published memories of former political prisoners (hereafter: PPs) containing references to music such as Valdés (1974), Carrasco (1977), Cassidy (1977), Durán Pardo (2003) and Jiménez and Izquierdo (2015), I have chosen to conduct ethnographies, using participant-observation, interviews and online crowdsourcing. I opted for this methodological approach for a number of reasons. First, the number of people who had musical experiences in detention is considerably larger than the number of people who have been able to write and publish their memoires. It is my belief that the more diverse voices contributing with memories, the richer the cultural legacy for present and future generations. Second, ethnographic methods allow probing questions that texts and other cultural production of witnesses may not touch upon. Third, I find personal interaction with witnesses very enriching, both personally and professionally.

My insider status as a Chilean and as the daughter of ex-PPs usually facilitates contacts and rapport with other ex-inmates. I have also conducted research with individuals who were not imprisoned but have played an

\footnotetext{
${ }^{2}$ The Valech report's references to music relate to Recinto CNI calle Azola, Regimiento de Infantería 19 Colchagua, Recinto CNI Piscicultura de Curicó, Recinto CNI calle Pedro de Valdivia 710, Regimiento La Concepción, aka Regimiento Andino, Academia de Guerra Aérea, Recinto DINA Londres 38 and Recinto DINA calle Irán 3037. This report summarised tens of thousands of testimonies from survivors and perpetrators. Owing to law 19,992 (Ministerio del Interior 2004), the original testimonies and identity of testimony givers have been secret despite numerous public campaigns to make these available to the public. These are now available to the courts as a result of a recent amendment to the aforementioned law (see Senado República de Chile 2017). The public is still prohibited from accessing the full Valech records, as well as the archives of the armed forces. Details of all political detention centres are found in the Museo de la Memoria y los Derechos Humanos's database Recintos: http://interactivos.museodelamemoria.cl/recintos/ (accessed 18 June 2017). For a study on Chilean truth commissions, see Ferrara (2014).

${ }^{3}$ Nevertheless, there has been significant cultural studies engagement with Ariel Dorfman's 1991 play Death and the Maiden, in which music has a central role (de Castro Jr. [1998], Schulz [2000], Schlickers [2004] and Caruth [2014], among others), and marginal discussions of music in studies such as Ramírez and Serpente's (2012) examination of a tree-planting ceremony in Wales, honouring Pinochet's victims.
} 
active role in commemorative music initiatives, as well as with officers of truth commissions and former members of Pinochet's secret services. Given the fast diminishing number of survivors, and to speed up the collecting process, I devised the ongoing digital project Cantos Cautivos (Captive Songs, www.cantoscautivos.org), which uses online crowdsourcing as the main method to gather content. Built in 2014-15, in collaboration with the Museum of Memory and Human Rights (Santiago, Chile), the archive continues to develop in partnership with several networks of ex-PPs in Chile and abroad. ${ }^{4}$ This project calls for recognistion of the importance of archival and documentary work relating to social and communal memory of human rights violations, in line with the ethos of initiatives that seek to generate new kinds of politically and socially productive public records such as the oral archives of Villa Grimaldi (Chile) and Memoria Abierta (Argentina).

During the course of my research, several contributors have stated that they had never shared their experiences of political imprisonment and torture before. I would argue that remembering through music, possibly the most subjective and emotional cultural form, enables witnesses to establish relationships with difficult experiences, facilitating, engaging with and contributing to memory processes, and opening up previously closed spaces. Thus, music is a possible answer to the question posed by Michael Lazzara (2006, 13): 'When a nation has suffered a traumatic and scarring episode, in what "languages" is it possible to convey the experience?'

In conducting interviews for this research, I have taken inspiration from Hollway and Jefferson's (2000) free association and narrative methods, asking general and open-ended questions. I am also keen to let ex-PPs choose whichever aspects of their experiences they want to discuss. Most generally, ex-PPs' answers describe music activities initiated by them that were relevant in terms of social engagement and empowerment. ${ }^{5}$ Testimonies dealing with these roles of music feature heavily in testimonies I have collected for the BBC project Canto Cautivo (2005) and web archive Cantos Cautivos, and in a sub-chapter of Jorge Montealegre's doctoral dissertation 'Acciones colectivas, memorias y procesos de resiliencia en la experiencia de prisioneras y prisioneros políticos de Chile y Uruguay' (2010, 307-326). Montealegre, himself a former PP, views agential uses of music and other cultural expressions as key factors in the development of what he terms resilencia comunitaria (communal resilience), which, he claims, emerged when prisoners recognised a common socio-cultural heritage, developed playful and humorous expressions within a mourning context, and valued and developed creativity (2010, 412-413). I would propose that ex-PPs' recollections of agential uses of music may also be related to one of the four emblematic memories of the dictatorship identified by Steve Stern (2002), namely memory as proof of ethical and democratic consequence in the face of a reality of repression and fear. ${ }^{6}$

\footnotetext{
${ }^{4}$ For a brief account of the Cantos Cautivos project, see Chornik (2015). I have yet to conduct an in-depth study of the contents of the archive, which has grown over four-fold since the aforementioned article was published.

${ }^{5}$ Whilst it is likely that ex-PPs prefer to hold on to positive memories (as most people do), it is also possible that their less forthcoming attitude to discussing misuses of music could signal associated trauma. Following ethical guidelines and my own instinct, I did not press with further questions on these particular aspects. Prior to interviews, research participants were given an Information Sheet explaining, among other things, the research's aims, the sensitive nature of interview topics, and participants' right to not answer questions and to discontinue interviews at any point. The document also made clear that people with conditions that could be aggravated through interviews must refrain from taking part in the study. My research was approved and overseen by the University of Manchester's Research Ethics Committee (UREC), and adheres to the ethics statements of the Society for Ethnomusicology and the British Forum for Ethnomusicology.

${ }^{6}$ The other three emblematic memories recognised by Stern (2002) are memory as salvation, memory as a lacerating and unresolved rupture, and memory as forgetting or closed box.
} 
Several ex-PPs have recounted experiences of being forced to sing or listen to loud music in ways that bring to mind some of the methods of 'no-touch torture' and the 'five techniques', used respectively by US and UK intelligence services. ${ }^{7}$ Although some of my interviewees recognised these experiences as harmful, when I asked them if they reported these to truth commissions they played down the effects or did not recognise these acts as torture or other cruel, inhuman and degrading treatment (hereafter: CIDT). Anna Papaeti $(2013,68)$ observes similar responses when interviewing ex-PPs of the Greek Junta (1967-1974), suggesting that these occur because 'reconstructing the abuse of music by the regime requires brushing against the grain of coherently constructed narratives [which view music as resistance] that have been relayed consistently for nearly 40 years'.

Papaeti's interpretation of the Greek ex-PPs' responses seems applicable to the Chilean case. I would also propose that Chilean ex-PPs' hesitation to regard misuses of music as ill-treatment may also be influenced by the fact that until November 2016 torture was technically not a crime in Chile as per the internal penal code, and by the limited definitions used for years by truth commissions and NGOs in charge of collecting testimonies, which although in theory considered both physical and psychological torture, in practice focused on phenomena that left physical marks only, as evidenced in their reports. ${ }^{8}$

Cases of music being employed against human rights have received widespread attention in and out of academia over the last decade, in relation to the so-called War on Terror. Yet the history of the misuse of music goes back at least to the Middle Ages and has been present in different areas of the world, as shown in two special issues edited by Morag Grant and Anna Papaeti (2013a, b). ${ }^{9}$ To my knowledge, there are no clinical studies focusing on the effects of misuses of music upon prisoners, in respect of any geographical context. However, some musicologists have suggested possible effects of forced listening. While Suzanne Cusick (2013) points toward the destruction of subjectivity and alterability of consciousness, Morag Grant $(2013,6)$ highlights physical effort and loss of sleep, noting that although the psychological damage is difficult to predict, "what we do know is that for some survivors, forms of torture involving music were viewed by them as amongst the worst they had experienced, while for others, it offered them a way to cope'. ${ }^{10}$

This article discusses memories of musical experiences lived by three ex-PPs I interviewed face-to-face in Santiago, Chile, in September 2013. Their names are Luis Cifuentes, Ernesto Parra and Ana María Jiménez. ${ }^{11}$

\footnotetext{
${ }^{7}$ I discuss the relationships between these in a forthcoming study. 'No-touch torture' and the 'five techniques' are examined by McCoy (2006) and Cobain (2012), among others.

${ }^{8}$ Torture was not part of the internal penal code despite the fact Chile had signed (1987) and ratified (1988) the UN Convention against Torture (1984). On 11 November 2016, the Chilean Senate finally passed a law that typifies and criminalises torture (Ministerio de Justicia y Derechos Humanos 2016).

${ }^{9}$ Cases of unethical uses of sound and music against detainees over the last decade were found in sixty-six countries by the former UN Special Rapporteur on Torture Manfred Nowak (Grant 2013b, 92). There are also recent reports of music being used by the US military against their own Air Force Academy cadets (Titon 2015).

${ }^{10}$ Those interested in therapeutic uses of music may consult Atarah Fisher and Avi Gilboa (2016, on Holocaust survivors), Susanne Bauer (2009, on settlers of the German sect Colonia Dignidad, southern Chile), and Boyles and Adcock (2013, on torture survivors living in Manchester, UK).

${ }^{11}$ Luis Cifuentes is Professor of Electrometallurgy at the University of Chile. A keen percussionist and charango player, he was an early member of the group Inti-Illimani. Luis was imprisoned at Estadio Nacional and Chacabuco, where he co-wrote several folk songs and participated in the group Los de Chacabuco. In addition to his scientific work, he has published extensively on music, politics and history topics. Ernesto Parra is a guitarist and conductor. While training as a biology teacher, he founded the Nueva Canción groups Los de la Peña and Los Curacas. Ernesto was imprisoned in the Comisaría de Carabineros No. 1, Dirección General de Investigaciones, Estadio Nacional, Chacabuco and Estadio Chile. In Chacabuco, he was co-leader of the band Los de Chacabuco. In 1999 he founded the Youth Orchestra Programme of
} 
Their memories included here relate to individual experiences taking place in Villa Grimaldi (Santiago), Dirección General de Investigaciones (Santiago), Estadio Nacional (Santiago) and Chacabuco (Atacama region). Of these centres, torture was most heavily practised in Villa Grimaldi and Estadio Nacional, where a large number of prisoners were executed or forcibly disappeared. None of my interviewees was charged with an offence. Their length of imprisonment ranged from four to nineteen months, after which they all went into exile. At the time of their arrest, they were aged between twenty-two and twenty-eight. All have a strong musical background, and were actively involved in music activities before, during and after detention. My choice of participants was deliberate, following my assumption that their particular background would generate richer answers to questions about music. The interviews were semi-structured and audio-recorded. Ex-PPs talked mostly about their agential uses of music in prison. Gently and well into the conversation, I asked if they could share any memories of misuses of music by State agents. I then shifted to less sensitive matters relating to the present and future. The interviews preceded the creation of, and are not included in, the Cantos Cautivos archive.

In what follows, I present, contextualise and interpret interview excerpts dealing with individual musical experiences in direct relation to torture and other CIDT. Rather than situating these particular experiences within the larger context they lived as prisoners, I have chosen to provide frameworks beyond imprisonment, discussing the specific songs, music genres and musical practices mentioned by the ex-PPs, and how these might link to their experiences. Evidently, my background and subjectivity have influenced the ways in which I have selected, edited and interpreted this material. Any errors are my own.

\section{'What music do you like?'}

Luis recalled that during an interrogation session at Estadio Nacional, torturers asked him: 'What music do you like?'. He told them: 'I like Vivaldi, Bach and Leo Dan.' Luis was referring to a line from the ballad 'Ding dong, las cosas del amor' (Ding, dong, matters of love), written by the Argentine singer-songwriter, actor and director Leonardo Favio, and recorded in 1969 by Favio and Zulema Carola Leyton. ${ }^{12}$ This song deals with a young man trying to seduce a schoolgirl he has met in the street. Opposing musical tastes are revealed through the young man's sung narrative and spoken dialogue with the girl. By the end of the song, however, the characters discover that they both like the popular Argentine singer-songwriter Leo Dan, himself a close collaborator of Favio:

Ding dong ding dong, there is no agreement in love if she says The Bee Gees, I tell her The Tremeloes

if she says Los Beatles, I tell her The Rolling Stones

[...]

If she says Los Gatos, I say Pintura Fresca

if she says Favio, I say Palito Ortega

Ding dong ding dong, to sing to love.

$[\ldots]$

La Reina (Santiago), directing it for seventeen years. At present he conducts the University of Santiago's Camerata Estudiantil. Ana María Jiménez trained as a music teacher and pianist at the University of Chile. She was detained in Villa Grimaldi, Cuatro Álamos and Tres Álamos. In Tres Álamos, she ran weekly music workshops and directed a choir of prisoners. In 2013, with other survivors she formed a new choir called Voces de la Rebeldía, which to the present day performs regularly in commemorative events in and around Santiago.

${ }^{12}$ A video clip and the full original lyrics of 'Ding dong, las cosas del amor' are found at https://www.youtube.com/watch?v=qL_GL-CjrUE (accessed 17 June 2017). 
- Do you like cinema?

- Yes.

- And music?

- Uh-huh, Vivaldi, Bach.

- Of course. Really, do you know who I like? Leo Dan

- Leo Dan?

- Yes.

- Uh-huh, me too

- Yes?

- Yes.

The aim of Luis's torturer's question about musical taste was to find out his political affiliation. This is explained by the active and visible involvement of musicians in left-wing politics prior to and during the Unidad Popular government, particularly those belonging to Nueva Canción (New Song), a pan-Latin American movement of multiple roots that originated in the 1960s. ${ }^{13}$

For instance, members of the groups Quilapayún and Inti-Illimani were supporters of the Partido Comunista, and the singer-songwriter Patricio Manns of the Movimiento de Izquierda Revolucionaria (MIR). ${ }^{14}$ Because people on the left shared similar ideals and values about social justice and equality, they preferred musicians who had their same political militancy.

Luis's quoting of Favio's song is remarkably witty. In response to his interrogator's demand for musical disclosure, he invokes the song's play on musical taste as a means to define personalities. Irony is generated in the clash between the content of the song and the context in which Luis recalls it. Irony is also produced at the expense of the agents, who, according to Luis, did not grasp the different layers of meanings in his response.

Issues of musical taste were also relevant for Ernesto while imprisoned at Dirección General de Investigaciones. He recalled a time when he heard his own torturer sing to him:

At one point, I lifted up the blindfold a little bit and saw that he was an enormous fat guy in a grey suit. He was singing a song. I came to the conclusion that this guy did this [the torture] as a job. His singing was sort of commonplace. And he sang every time, so naturally. I used to think, 'What's this scumbag thinking about? He's beating the shit out of me and singing as if it were nothing, as if it were so normal'. I've never been able to remember what song it was, but it was a well-known song of the time, that wasn't popular in our crowd. It was some type of bolero, cumbia or ranchera. You'd be so immersed in another type of music that you couldn't even identify what he was singing.

Ernesto suggests a dichotomy between the music of his social group (dominated by Nueva Canción) and the unidentified song that the torturer sings. The song is likely a bolero, cumbia or ranchera, genres respectively

\footnotetext{
${ }^{13}$ In Chile, Nueva Canción was born of, and represented, the spirit of the popular progressive struggles of the epoch. Víctor Jara, Ángel Parra, Isabel Parra, Patricio Manns and the groups Quilapayún and Inti-Illimani were some of the central figures of the movement. Nueva Canción expressed the aspirations and values of new cultural and political movements 'from below', often through socially conscious lyrics and folk-inspired music. It was also crucial because it denounced the injustices of Chilean society and communicated the new relations of social equality that were changing the face of Chile in the 1960s and early 1970s. Nueva Canción musicians were particularly targeted by the Pinochet dictatorship (McSherry 2015; see also Torres 1980; Carrasco 1982; and Rodríguez Musso 1988).

${ }^{14}$ MIR was not part of the Unidad Popular coalition.
} 
born in Cuba, Colombia and Mexico. ${ }^{15}$ All of these genres have been widely popular in Chile and have been adopted by local musicians. Although numerous songs in these genres have no overtly political lyrics and have been performed in Chile primarily or exclusively for non-political purposes, there are undercurrents that challenge the blanket labelling of these genres as apolitical. ${ }^{16}$

Ernesto's differentiation and distancing from his torturer's music do not seem to be dictated by specific music genres and their perceived apolitical nature but by the fact that the song is being sung as a soundtrack to grievous harm. Ernesto's perception of it as something morally condemnable and irremediably alien probably would remain unchanged, regardless of the song's genre. The perpetrator's singing is also disturbing as it normalises the act of torture, transforming it into an ordinary occupation.

\section{'You are going to sing to keep us entertained'}

One of the episodes Ana María remembered most vividly from her time at Villa Grimaldi involved forced singing. The incident happened during a winter's night, when all prisoners were formed-up in the patio. A DINA agent asked who was a musician. When Ana María identified herself, the agent demanded she sing: 'We're all bored here and it's such a cold night, so you are going to sing to keep us entertained'. The agent threatened Ana María that if she did not obey, all the prisoners would have 'a rough time'. Ana María recalled:

Despite the fear I felt, I decided that my small act of rebellion would be not to sing. Plus, I really thought that I wasn't going to be able to sing and was afraid that they would take me back for electric shocks.

But when the guard briefly left to obtain cigarettes, another detainee persuaded Ana María to sing, not to please the jailer but to comfort another prisoner called Cedomil Lausic who, after a brutal torture session at La Torre (the most feared section of the Villa Grimaldi complex), was suffering in solitary confinement at some distance. When the agent came back, Ana María sang 'Zamba para no morir' (Zamba so as not to die), a song written by Hamlet Quintana, Norberto Ambrós and Héctor Rosales, and popularised by Mercedes Sosa, a prominent figure of Nueva Canción in Argentina. ${ }^{17}$ Ana María sang that song often before being detained.

The song's protagonist, in death throes, voices feelings of solitude and hope for transcendence:

\footnotetext{
${ }^{15}$ For overviews of these genres, see Torres (2013).

${ }^{16}$ Rancheras (and the closely-related corridos) developed significantly during the Mexican Revolution (c. 1910-1920); their lyrics often narrate political events. Rancheras can be said to have political connotations when adopted by musicians who have had notable political roles, as in the cases of Patricio Manns and the groups Inti-Illimani and Quilapayún, who have performed and recorded various examples, as well as some boleros and cumbias. 'El africano' by the Colombian singer-songwriter Calixto Ochoa is an interesting case of politicisation of cumbias in Chile (Karmy Bolton et al. 2011). The song, which was very popular in the 1980s, became an emblematic protest song against Pinochet. In particular, to the original chorus line 'Mami ¿qué será lo que quiere el negro?' (Mummy, what would the black man want?) audiences added 'que se vaya Pinochet' (that Pinochet goes), singing the altered version in the streets and parties. The Chilean tropical music band Orquesta Cubanacán, believed to be supporters of Pinochet, paradoxically decided to play 'El africano' at the 1986 Festival de Viña del Mar, even though organisers had asked them not to. As expected, the audience roared the protest line in response. A manipulated recording of the Festival performance is found at https://www.youtube.com/watch?v=CZDNbXLPwGc (accessed 17 June 2017).

${ }^{17}$ Mercedes Sosa (1935-2009), known as 'the voice of the voiceless', was a celebrated Argentine singer and political activist. She rose to fame in the 1960s. Sosa suffered harassment and death threats during the Argentine dictatorship years (1976-1983), which forced her to flee to Europe. She returned to Argentina in 1982. For further details on Sosa's career, see Scruggs (2016) and Molinero and Vila (2014).
} 
My voice will ring through the afternoon

until the echo of yesterday.

In the end, I am left alone

dying of thirst, tired of walking

but I continue to grow in the sun... I live. ${ }^{18}$

Ana María chose 'Zamba para no morir' in the hope that it would lend some strength to Cedomil. Singing at the top of her lungs, she saw that 'all of my comrades had tears rolling down their faces and I don't know where I got the strength but my voice began to lift up as I sang, like it was in flight'. The agent abruptly stopped her and told her not to overstep her bounds 'with cute little political songs and to instead sing a cumbia or a song by Roberto Carlos'.

In her response to Ana María's singing, the agent seems to have invoked the common perception of cumbia and of the Brazilian singer-songwriter Roberto Carlos's music as apolitical. Whilst Roberto Carlos's songs are mostly concerned with romantic love, the musician made an explicit statement of political support for Pinochet during his 1975 performance at the Viña del Mar International Song Festival, attended by the dictator himself: 'For me, the presence of a country's president is a pride. Thanks very much, Mr. President, thanks very much, Sir Augusto Pinochet. ${ }^{19}$

At Villa Grimaldi, Ana María did not comply with the agent's request for a cumbia or a song by Roberto Carlos, and therefore was punished: she was obliged to spend the entire night in the rain. She recalled: 'I was cold and afraid but I felt I had performed a minimal act of resistance.' She later learned that her singing of 'Zamba para no morir' was the last thing Cedomil heard before passing away.

Ana María also experienced Roberto Carlos as a soundtrack to torture through his song 'Un millón de amigos' (A million friends), in addition to 'Gigi l'amoroso' (Gigi the ladies' man), a pop song written by Jacqueline Misrahi, Lana and Paul Sebastian, and popularised by the French-Italian singer Dalida:

At Villa Grimaldi they made you listen to recorded music, which was insufferable. You heard it day and night. I physically felt the music. It was Kafkaesque: you heard the screams of the inmates and, amid all that, the music and commentary of the guards. You lived a permanent torture session because if they weren't torturing you, you were listening to the torture of others, which was absolutely unbearable. And with music the whole time. The two songs that were most often heard were 'Un millón de amigos' and 'Gigi l'amoroso'. When they would come to torture you, they used to say 'here comes Gigi the ladies' man'. They sang the song and they loved to feel like they were Gigi. They used to put that song on at full blast while they performed the torture, at extremely high volume. Even so, I still like Roberto Carlos.

\footnotetext{
${ }^{18}$ The full original lyrics of 'Zamba para morir' and a recording by Mercedes Sosa are found at https://www.youtube.com/watch?v=RrIKHFhKSfA (accessed 17 June 2017). Cedomil Lausic was executed in April 1975. See Museo de la Memoria y los Derechos Humanos's database Víctimas: http://interactivos.museodelamemoria.cl/victimas/?p=1553 (accessed 7 June 2017).

${ }^{19}$ Roberto Carlos's address to Pinochet is found at https://www.youtube.com/watch?v=Esss7EOAOQo (accessed 6 March 2017). Roberto Carlos (1941-), aka The King of Latin Music, came to the forefront in the mid-1960s, during the early days of the Brazilian dictatorship, through the TV programme 'Jovem Guarda' (Young Guard). This programme featured a type of youth music called $i \hat{e}$, $i \hat{e}$, iê. Roberto Carlos and other 'Jovem Guarda' artists viewed their music as apolitical and palliative to political conflict. For further details of Roberto Carlos's career and 'Jovem Guarda', see de Araújo (2006) and Fróes (2000).
} 
The agents' choice of 'Gigi l'amoroso' is significant. Employed in a torture chamber, it links the donjuanesque power of the song's male character to Pinochet's agents' systematic use of sexual violence against women prisoners:

\author{
When Gigi appears \\ the hurrahs and the cheers \\ come from the crowd as he begins to sing. \\ And in between each song \\ they shout and sing out strong \\ We love you Gigi l'amoroso \\ the greatest Italian lover since man discovered fire \\ Gigi l'amoroso \\ if you only knew what you make us do \\ with your songs of desire. ${ }^{20}$
}

\begin{abstract}
Although Ana María did not make a connection when I asked her specifically about this, to me the agents' choice of 'Gigi l'amoroso' suggests a word play on gigí, a DINA slang term that denoted the device generating electric shocks to torture prisoners. ${ }^{21} \mathrm{It}$ is possible that this term in turn originated from the previous French argot gégène (short for génératrice), meaning a magnetic torture device. ${ }^{22}$ As Darius Rejali $(2009,144)$ explains, in the late 1950s the term gégène became notorious in France and Algeria; the word gégéneur (the person operating the gégène) was used as synonymous for torturer. ${ }^{23}$ Gégène being a torture technique developed by previous military interventions on other continents, its appropriation by Chilean perpetrators is accomplished with the support of the song 'Gigi l'amoroso', epitomising their cruelty and sadism when announcing to Ana María: 'Here comes Gigi the ladies' man.'
\end{abstract}

\title{
'I would look for that song because it was reassuring'
}

According to Ernesto's and Luis's accounts, at the time of arrest some prisoners were carrying portable radio receivers in their pockets. Not all devices were discovered and confiscated by prison authorities. Therefore, some circulated clandestinely among prisoners, allowing them to listen to music and to the news. Prisoners with technical skills also manufactured radio receivers secretly.

On a radio receiver circulating in the dressing rooms of Estadio Nacional, Luis listened to a specific song to build up courage for imminent torture sessions: 'I had an obsession for 'Morning has broken' by Cat Stevens, and when a supportive comrade would lend me a receiver I would look for that song because it was reassuring. ${ }^{24}$

\footnotetext{
${ }^{20}$ A video clip of the Spanish version of 'Gigi l'amoroso' that was popular in Chile in the 1970s is found at https://www.youtube.com/watch?v=K7zApAPLxto (accessed 17 June 2017).

${ }^{21}$ The term gigí was used by personnel operating at the clandestine torture chamber on Simón Bolívar Street in Santiago (Rebolledo 2012, 129). It is likely that the term was employed elsewhere, given that Pinochet's agents often operated in several centres simultaneously.

${ }^{22}$ I thank Manuel Guerrero Antequera for drawing my attention to the term gégène and its use by the French in Algeria.

${ }^{23}$ Alongside France, the United States and Chile were among the main electro-torture users during the period 1945-1979, according to Rejali (2009, 168-169).

${ }^{24}$ The British singer Cat Stevens (currently known as Yusuf Islam) did not write 'Morning has broken' but reinterpreted a traditional hymn based on a nineteenth-century Gaelic melody, to which the English writer Eleanor Farjeon (18811965) composed a poem. Stevens's version was very popular in Chile in the 1970s. A video clip is found at https://www.youtube.com/watch?v=X48weyESpec (accessed 17 June 2017).
} 
One may suggest that the song's idyllic verses referring to the book of Genesis - 'Morning has broken, like the first morning / blackbird has spoken, like the first bird' - provided an imaginary scene that contrasted with the gloomy cells in which Luis and other prisoners were confined. When existence was so uncertain, the song's dealings with the passing of time, and its simple and regular harmonies, would have probably provided hope, and a sense of continuity and agency.

Ernesto also listened to certain songs that were broadcast on the radio before and after being tortured at Estadio Nacional. For him, the two key songs were 'Without you' by Pete Ham and Tom Evans, and 'Alone again, naturally' by Gilbert O'Sullivan. Both songs emphasise suffering and loss: while the former concerns the break-up of a relationship, the latter explores the emotions of a person in a full-blown existential crisis, hinting at suicide. Another song that helped Ernesto transcend torture was 'Clair', also by O'Sullivan, which recounts the quasi-incestuous feelings of a man towards his young niece. ${ }^{25}$ One could imagine that Ernesto's emotional attachment to the aforementioned three songs was not because of the dubiously comforting lyrics (whose meaning may have been lost in translation) but because of the simplicity and lightness of their melodies.

\section{Conclusion}

This essay presented three former prisoners' recollections of musical experiences in direct relation to torture and other CIDT, including music employed by the regime to aggravate them, and their own uses of music to build and sustain courage in the face of ill treatment, and to express solidarity with others. Due to this research being qualitative and dealing with the experiences of three ex-PPs (out of ca. 40,000) in four political detention centres (out of a total of 1,168), it is my view that their memories should be seen in their uniqueness and specificity. Thus, I shall not aim to meet the prevailing expectation that scholarly research should make general conclusions, extrapolating from particular examples to wider phenomena. I would propose that a study seeking to outline the roles of music in the dictatorship's entire political detention system should examine a much larger and more diverse number of participants, and cover many more detention centres and social dynamics, among other variables. Only then will researchers be able to establish reliable parameters.

Although the stories presented in this essay are not necessarily representative of the tens of thousands who suffered political imprisonment and torture under Pinochet, they help contribute to understanding some of the multivalent ways in which music featured in these contexts, adding further evidence to Montealegre's (2010) research on political prisoners' collective cultural resilience, and to my research (Chornik 2014) on the musical memories of a former member of the DINA secret police. ${ }^{26}$

Focusing on ex-PPs individual experiences and connecting these with phenomena beyond imprisonment have, however, brought different results. I shall highlight three common points in the ways in which captives and captors viewed music, namely the linking of musical taste to political militancy (seen in the testimonies of Luis and Ernesto), the invoking of perceived music apoliticisms (seen in the testimonies of Ernesto and Ana María), and the playing on various levels of linguistic meanings attached to song lyrics (seen in the

\footnotetext{
${ }^{25}$ See video clips of 'Without you' (https://www.youtube.com/watch?v=sPgeKcOalxc), 'Alone again, naturally' (https://www.youtube.com/watch?v=EKZkkTBd2_A), and 'Clair' (https://www.youtube.com/watch?v=sU9fClvdo5s).

${ }^{26}$ That former DINA agent has been recently sentenced for his role in the Operation Colombo, a major operation implemented by the DINA in 1975 in close collaboration with Argentine services to cover up the assassination of 119 victims. Operation Colombo was part of the larger multi-national Operation Condor.
} 
testimonies of Ana María and Luis). Whilst these points may appear non-central to overall experiences of political imprisonment, one may suggest that they represent a challenge to the notion that the worldviews of survivors and those of perpetrators have nothing in common whatsoever. These findings also challenge my own previous proposal (Chornik 2014, 123) that the experiences of survivors, perpetrators, accomplices, witnesses and spectators, and their diverse combinations, are too different to be studied through a comparative lens.

Working on the topic of music and human rights violations involves a myriad of ethical challenges. Publishing the stories included in this article, in particular, has been difficult for me, given the unfortunate voyeurism and sensationalism that has accompanied some media coverage and scholarly studies on music in torture contexts in recent years. The latter has included work on the 'field' of 'music torture', and work carried out by colleagues who have never had contact with torture survivors. Some of these studies, in my view, do not show much empathy with survivors, and raise questions that resonate with those posed by Clelia Rodríguez in her provocatively titled article 'How Academia Uses Poverty, Oppression, and Pain for Intellectual Masturbation' (2017), particularly in relation to the acquisition of knowledge from vulnerable populations and subsequent use for career advance, without taking into account the needs of the researched communities. As well as acting upon the aforementioned issues and creating horizontal working relationships with survivors, at the heart of my concerns has been the question of how to balance their and my personal wish to make these stories public inside and outside academia, with the duty of acting ethically above and beyond individual and institutional research agendas.

\section{Acknowledgements}

This research forms part of my 2013-16 research project 'Sounds of Memory: Music and Political Captivity in Pinochet's Chile (1973-1990)', conducted at the University of Manchester and supported by the Leverhulme Trust under grant number ECF-2013-403. I am indebted to the survivors I have interviewed, who have been very generous in sharing their memories. I also thank Stephen Millar, Patrice McSherry and Cristián Peña for their useful suggestions.

\section{References}

Bauer, Susanne. 2009. "The Meaning of Music in a German Sect in Chile: Colonia Dignidad.” Voices Resources. Accessed 9 January 2017. http://testvoices.uib.no/community/?q=colbauer200409 Blacking, John. 1973. How musical is man? London: Faber \& Faber.

Boyles, Jude, and Christine Adcock. 2013. "Stone Flowers." Healthcare Counselling \& Psychotherapy Journal 13 (4): 32-39.

Carrasco, Eduardo. 1982. La nueva canción en América Latina. Santiago, Chile: CENECA.

Carrasco, Rolando. 1977. Prigué. Moscow: Novosti Press.

Caruth, Cathy. 2014. "Disappearing History: Scenes of Trauma in the Theater of Human Rights." In Knowing the Suffering of Others, edited by Austin Sarat, 170-200. Tuscaloosa: The University of Alabama Press.

Cassidy, Sheila. 1977. Audacity to Believe. Cleveland: Collins World.

Chornik, Katia. 2005. "Canto Cautivo.” BBC Mundo. Accessed 8 July 2017. http://news.bbc.co.uk/hi/spanish/specials/2005/canto_cautivo

Chornik, Katia. 2013. "Defiant Notes: The Choir Founded in Chile's Detention Camps." BBC News, September 11. Accessed 5 June 2017. http://www.bbc.co.uk/news/world-latin-america-24014509 
Chornik, Katia. 2014. "Música y tortura en centros de detención chilenos: conversaciones con un ex agente de la policía secreta de Pinochet." Resonancias 34:111-126. Accessed 5 June 2017. http://resonancias.uc.cl/images/articulos_N34/N34/N_34.pdf

Chornik, Katia. 2015. "Cantos Cautivos: Online Archive of Songs of Political Captivity in Pinochet's Chile." Leonardo Music Journal 25: 102-103

Chornik, Katia, ed. Cantos Cautivos. http://www.cantoscautivos.org

Cobain, Ian. 2012. Cruel Britannia: A Secret History of Torture. London: Portobello Books.

Comisión Nacional sobre Prisión Política y Tortura I [Comisión Valech]. 2004. "Informe.” Accessed 17 June 2017. http://www.archivochile.com/Derechos_humanos/com_valech/ddhhvalech0021.pdf

Cusick, Suzanne G. 2013. "Towards an Acoustemology of Detention in 'the Global War on Terror'." In Music, Sound and Space: Transformations of Public and Private Experience, edited by Georgina Born, 275-291. Cambridge: Cambridge University Press.

de Araújo, Paulo Cesar. 2006. Roberto Carlos Em Detalhes. São Paulo: Planeta do Brasil.

de Castro Jr., Pércio B. 1998. “La muerte y la doncella: ¿De quién son las bolas? Opresor oprimido y viceversa." Revista Chilena de Literatura 52: 61-67.

Durán Pardo, Claudio. 2003. Autobiografía de un ex-jugador de ajedrez. Santiago de Chile: Lom Ediciones.

Ferrara, Anita. 2014. Assessing the Long-Term Impact of Truth Commissions: The Chilean Truth and Reconciliation Commission in Historical Perspective. Abingdon: Routledge.

Fisher, Atarah, and Avi Gilboa. 2016. "The Roles of Music amongst Musician Holocaust Survivors before, during, and after the Holocaust." Psychology of Music, 44 (6): 1-19.

Fróes, Marcelo. 2000. Jovem Guarda: em ritmo de aventura. São Paulo: Editora 34.

Grant, M. J. 2013. “The Illogical Logic of Music Torture.” Torture Journal 23 (2): 4-13.

Grant, M. J., and Anna Papaeti. 2013a. Special issue "Music and Torture | Music and Punishment." The world of music (new series) 2 (1).

Grant, M. J., and Anna Papaeti. 2013b. Thematic issue on music in detention. Torture Journal 23 (2).

Accessed 12 June 2017. http://irct.org/publications/torture-journal/117.

Hollway, Wendy, and Tony Jefferson. 2012. Doing Qualitative Research Differently. 2nd ed. London: SAGE.

Jiménez, Ana María, and Teresa Izquierdo. 2015. Antes de perder la memoria. Santiago de Chile: Editorial Cuarto Propio.

Karmy Bolton, Eileen, et al. 2011. ¿Roja, militar, apolítica? Notas sobre cumbia y politicidad.” Tiesos pero cumbiancheros. Accessed 29 January 2017. http://www.tiesosperocumbiancheros.cl/?p=139

Lazzara, Michael J. 2006. Chile in Transition: The Poetics and Politics of Memory (Gainesville: University Press of Florida).

McCoy, Alfred. 2006. A Question of Torture: CIA Interrogation, from the Cold War to the War on Terror. New York: Owl Books.

McSherry, J. Patrice. 2015. Chilean New Song: The Political Power of Music. Philadelphia: Temple University Press.

Ministerio de Justicia y Derechos Humanos. 2016. "Tipifica delitos de tortura y de tratos crueles, inhumanos y degradantes.” Biblioteca del Congreso Nacional de Chile. Accessed 27 December 2016. https://www.leychile.cl/Navegar?idNorma=1096847.

Ministerio del Interior. 2004. "Establece pensión de reparación y otorga otros beneficios a favor de las personas que indica." Biblioteca del Congreso Nacional de Chile. Accessed 26 September 2017. https://www.leychile.cl/Navegar?idNorma=233930.

Molinero, Carlos, and Pablo Vila. 2014. "A Brief History of the Militant Song Movement in Argentina." In The Militant Song Movement in Latin America: Chile, Uruguay, and Argentina, edited by Pablo Vila, 193-228. Laham: Lexington Books.

Montealegre, Jorge. 2010. “Acciones colectivas, memorias y procesos de resiliencia en la experiencia de prisioneras y prisioneros políticos de Chile y Uruguay.” PhD diss, Universidad de Santiago de Chile. 
Museo de la Memoria y los Derechos Humanos. [n.d.]. Víctimas. Accessed 17 June 2017. http://interactivos.museodelamemoria.cl/victimas

Papaeti, Anna. 2013. "Music, Torture, Testimony: Reopening the Case of the Greek Military Junta (19671974)." The world of music (new series) 2 (1): 67-89.

Ramírez, Carolina, and Alejandra Serpente. 2012. "Ecomemoria's Diasporic Space of Commemoration: A Tree-Planting Ceremony and its Living Memorial." Journal of Latin American Cultural Studies 21 (2): 189-202.

Rebolledo, Javier. 2012. La danza de los cuervos: el destino final de los detenidos desaparecidos. Santiago de Chile: Ceibo Ediciones.

Rejali, Darius. 2009. Torture and Democracy. Princeton: Princeton University Press.

Rodríguez, Clelia O. 2017. "How Academia Uses Poverty, Oppression, and Pain for Intellectual Masturbation." RaceBaitR. Accessed 19 June 2017. http://racebaitr.com/2017/04/06/how-academiauses-poverty-oppression/\#

Rodríguez Musso, Osvaldo. 1988. La Nueva Canción Chilena: continuidad y reflejo. Havana: Casa de las Américas.

Schlickers, Sabine. 2004. "Tortura, amnesia y amnistía: La muerte y la doncella de Ariel Dorfman y de Roman Polanski." In Memoria, duelo y narración. Chile después de Pinochet: literatura, cine, sociedad, edited by Roland Spiller et al., 55-68. Frankfurth am Main: Vervuert.

Schulz, Bernard. 2000. "Lo difuso de la política en la versión cinematográfica de La muerte y la doncella." Revista Chilena de Literatura 56: 127-134.

Scruggs, T.M. 2016. "Singing Truth to Power: Mercedes Sosa, 1935-2009." NACLA Report on the Americas 42 (6): 4-5.

Senado República de Chile. 2017. "Comisión Valech I: Comisión de DDHH despacha texto legal”, 14 September. Accessed 20 September 2017.

http://www.senado.cl/comision-valech-i-comision-de-ddhh-despacha-texto-legal/prontus_senado/2017-0913/195436.html.

Stern, Steve J. 2002. "De la memoria suelta a la memoria emblemática: hacia el recordar y el olvidar como proceso histórico (Chile, 1973-1998)." In Las conmemoraciones: Las disputas en las fechas "infelices", edited by Elizabeth Jelin, 11-33. Madrid: Siglo XXI.

Titon, Jeff Todd. 2015. "Music, Torture, and the APA." Sustainable Music: A Research Blog on the Subject of Sustainability and Music, 19 July. Accessed 27 December 2016.

http://sustainablemusic.blogspot.co.uk

Tofft, Carl, dir. 2010. Music Som Gör Ont. Sveriges Television AB.

Torres, George, ed. 2013. Encyclopedia of Latin American Popular Music. Santa Barbara, CA: Greenwood.

Torres, Rodrigo. 1980. Perfil de la creación musical en la Nueva Canción Chilena desde sus orígenes hasta 1973. Santiago, Chile: CENECA.

Valdés, Hernán. 1974. Tejas Verdes: diario de un campo de concentración en Chile. Barcelona: Ariel. 